\title{
LP9M80-H Isolated from Liriope platyphylla Could Help Alleviate Diabetic Symptoms via the Regulation of Glucose and Lipid Concentration
}

Ji Eun Kim¹, In Sik Hwang', Jun Seo Goo', So Hee Nam¹, Sun ॥ Choi, ${ }^{1}$ Hae Ryun Lee', Young Ju Lee', Yoon Han Kim², Se Jin Park², Nahm-Su Kim³, Young Hwan Choi' and Dae Youn Hwang'*

${ }^{1}$ Department of Biomaterials Science, ${ }^{2}$ Department of Horticultural Bioscience, College of Natural Resources \& Life Science, Pusan Nationai University, Miryang 627-706, Korea

${ }^{3}$ Technology Cooperation Bureau, Rural Development Administration, Suwon 441-707, Korea

Received February 28, 2012 /Revised March 23, 2012 /Accepted March 27, 2012

It was reported that the novel compounds (LP9M80-H) of Liriope platyphylla regulate glucose transporter (Glut) biosynthesis by activating the insulin-signaling pathway in the liver and brain of ICR mice. To investigate the therapeutic effects of LP9M80-H on the pathology of diabetes and obesity, alterations of key factors related to symptoms were analyzed in the Otsuka Long Evans Tokushima Fatty (OLETF) rats treated with LP9M80-H for 2 weeks. The abdominal fat masses in the LP9M80-H-treated group were lower than the vehicle-treated group, although there was no difference in body weight between the two groups. Additionally, when compared to the vehicle-treated group, LP9M80-H treatment induced a significant decrease in glucose levels and an increase in the insulin concentration in the blood of OLETF rats. A high level of insulin protein was also detected in pancreatic $\beta$ cells of LP9M80-H-treated OLETF rats. A significant reduction in the concentration of lipids and adiponectin was detected only in LP9M80-H-treated OLETF rats. Furthermore, the expression of insulin receptor $\beta$ and the insulin receptor substrate (IRS) was dramatically decreased in LP9M80-H-treated OLETF rats compared to the vehicle-treated group. Of the glucose transporters located downstream of the insulin-signaling pathway, glucose transporters (Glut) -2 and -3 were significantly decreased in LP9M80-H-treated OLETF rats, while the level of Glut-4 was maintained under all conditions. Therefore, these results suggest that LP9M80-H may contribute to relieving symptoms of diabetes and obesity through glucose homeostasis and regulation of lipid concentration.

Key words : Liriope platyphylla, diabetes, fat, OLETF rat

\section{서 론}

당뇨병은 인슐린의 생산 부족 또는 표적 세포의 부적절한 반응으로 일어난 높은 혈당 농도가 특징인 질병이다[18]. 전통 적으로 췌도 이식술, 인슐린 섭취, 신약 개발과 같은 많은 치료 전략이 이러한 대사 장애의 치료에 시도되고 있지만, 대부분 의 연구는 인슐린 분비 능력 향상과 당뇨병 증상을 개선하기 위한 인슐린 감도를 개선하는 분자를 찾는데 주력하고 있다 [6]. 인슐린 신호, 경구 혈당 강하제, 각종 보완 및 대체의학에 포함되는 분자들은 다양한 천연재료에서 화학합성 및 추출로 개발 될 수 있다[11]. 지금까지 천연물의 많은 구성성분들이 당뇨병의 치료에 사용되고 있다. 당뇨병에 사용되고 있는 Liriope platyphylla Wang et Tang, Momordica charantia L., Pterocarpus marsupium Roxb. 그리고 Trigonella foenum L. 등을 포함한 410 개의 약용 식물이 당뇨병의 치료에 사용되고 있지 만 오직 109 개의 식물에서만 당뇨 치료의 구체적인 효능과

*Corresponding author Tel : +82-55-350-5388, Fax : +82-55-350-5389

E-mail : dyhwang@pusan.ac.kr
메커니즘이 알려져 있다[9,14].

맥문동(Liriope platyphylla)은 북반구의 온대지방에 널리 분포하는 다년생식물로서 근경(vegetative rhizomes)과 종자 를 통해 번식할 수 있는 식물이다[10]. 오래 전부터 맥문동 은 한국과 중국에서 기침, 가래 등의 질병치료제로 한방에 서 주로 사용되어 왔으며, 최근에는 당뇨·비만 치료, 기억력 증진, 미생물 성장 억제, 염증억제 등의 기능이 알려져 있다 $[15,19]$. 이러한 기능 중에서 맥문동의 당뇨와 비만에 대한 효과는 일부 연구에서 확인되었다. 맥문동의 homoisoflavone-enriched fraction을 분리하여 3T3-L1 adipocytes에 처리하면, 인슐린 농도와 glucose uptake가 증가되었다. 이 러한 결과는 맥문동의 추출물이 인슐린 sensitizer로서 기능 을 제시하고 있다[3]. 또한 OLETF 랫드에 8주 동안 맥문동 이 첨가된 경신강제환을 투여하여 체중, leptin 농도, 먹이섭 취량, peroxisome proliferator-activated receptor alpha (PPAR-a) 발현 등의 감소현상을 관찰했다[8]. 그러나 스팀 과 건조과정을 반복하여 제조된 가공 맥문동의 hexane 추출 물을 비만·당뇨 모델 동물에 투여하여 그 효능을 평가한 연 구는 아직 수행되지 않고 있다. 
따라서, 본 논문에서는 증숙된 맥문동에서 $\mathrm{MeOH}$ 과 hexane을 이용하여 추출한 LP9M80-H가 OLETF 랫드에서 당뇨 와 비만에 미치는 영향을 알아보고자 하였다. 그 결과 LP9M80-H 물질이 인슐린 분비를 촉진시키고, 혈중 지방농도 를 낮춰주는 효과를 확인함으로써 당뇨와 비만 치료제로서의 가능성을 제시하고 있다.

\section{재료 및 방법}

\section{맥문동의 표제 및 추출}

맥문동은 2009년 5월에 밀양지역에서 재배된 괴근으로 밀 양 한약재 판매상으로부터 구입하여 전통적인 방법으로 맥문 동 괴근을 찐 다음 햇볕에 말리기를 9회 반복하여 제조한 구증 구포 재료(LP9)를 $-20^{\circ} \mathrm{C}$ 에 보관하면서 시료로 사용하였다. 구 증구포한 괴경 $1 \mathrm{~kg}$ 을 $80 \% \mathrm{MeOH}$ 로 3회 반복 추출한 $80 \%$ $\mathrm{MeOH}$ 추출물을 회전증발기로 $\mathrm{MeOH}$ 를 증발한 다음 남은 물층에 $1,200 \mathrm{ml}$ 의 hexane을 가한 다음 분획여두로서 hexane 추출물을 3 회 분획하여 hexane 추출물 $0.410 \mathrm{~g}$ 의 $\mathrm{LP} 9 \mathrm{M} 80-\mathrm{H}$ 을 얻었다(Fig. 1).

\section{동물실험 설계}

실험에 사용된 OLETF 랫드는 유전적으로 늦게 발현되는 경증의 비만과 제 2 형 당뇨의 변화를 나타내어 비만, 당뇨의 약물치료 실험에 많이 이용되는 모델이다[17]. Specified pathogen-free (SPF) 상태의 OLETF 랫드 $(20$ 주령, $300 \pm 30 \mathrm{~g})$ 를 오츠카제약(주)(Japan)에서 제공받았으며, 방사선이 조사된 사료(Purina, Seoungnam, Korea)를 자유급식하도록 하였고, 12 시간의 조명주기(08:00 12:00)로 SPF 상태인 부산대학교 청 정실험동물센터 $\left(\right.$ 온도 $22 \pm 1^{\circ} \mathrm{C}$, 상대습도 $50 \pm 5 \%$ )에서 사육하 였다. 또한 본 연구는 부산대학교 동물실험윤리위원회(PNU$\mathrm{IACUC}$ )로부터 과학성과 윤리성에 대한 심사를 거쳐 승인(승 인번호: PNU-2010-00098)을 받아 수행되었다.

실험동물을 5마리씩 3군(LETO군, OLETF-Vehicle군, OLETF-LP9M80-H 처리군)으로 무작위로 배정하였다. LETO 군은 LETO 랫드에 아무것도 처리하지 않았고, Vehicle처리군 은 OLETF 랫드에 olive oil 만을 격일로 2주 동안 $2 \mathrm{ml}$ 회씩 경구 투여하였고, LP9M80-H 처리군은 OLETF 랫드에 LP9M80-H를 $40 \mathrm{mg} / \mathrm{kg}$ 의 농도로 olive oil에 희석하여 격일 로 2주동안 $2 \mathrm{ml} /$ 회씩 경구 투여하였다. 2주 경과 후 모든 랫드는 $\mathrm{CO}_{2}$ 가스를 이용해서 안락사하여 혈액과 조직들을 적 출하였다.

\section{체중 및 지방무게 측정}

랫드의 체중은 경구투여 전과 부검 전에 화학저울(Mettler toledo, Greifensee, Switzerland)을 이용하여 측정하였다. 지 방의 무게는 2주 동안 물질을 처리한 후 $\mathrm{CO}_{2}$ 가스를 이용해서

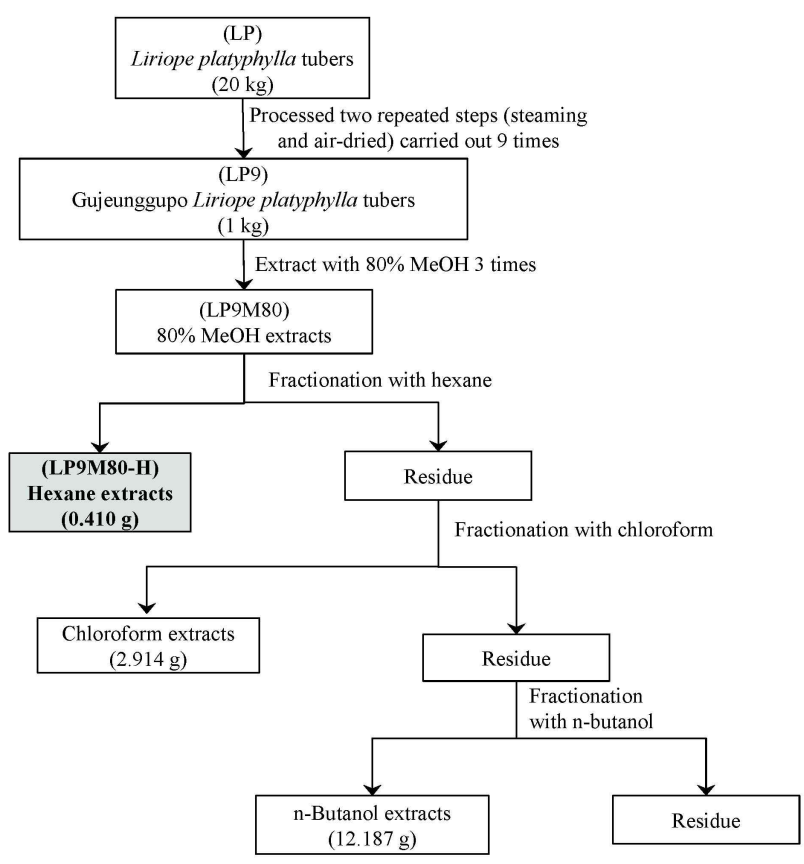

Fig. 1. Schematic process of LP9M80-H extraction from Liriope platyphylla.

안락사하여 복부지방을 적출하여 측정하였다.

\section{혈당량 측정}

랫드의 혈당량은 경구투여 전과 부검 전에 실험동물의 꼬리 정맥을 절단하여 혈당측정기(CareSens $\Pi$, Seoul, Korea)를 이 용하여 측정하였다.

\section{인슐린 분비량 측정}

LP9M80-H에 의한 인슐린 분비량은 Mercodia사의 Insulin ELISA kit (Cat.10-1113-01)를 이용하여 권장법에 따라 측정하 였다. 먼저 랫드의 혈액을 상온에서 30 분간 방치한 후 원심분 리하여 혈청을 분리한다. 분리된 혈청은 ELISA kit의 각 well 에 $25 \mu \mathrm{l}$ 씩 넣고, $100 \mu \mathrm{l}$ 의 enzyme conjugate solution을 첨가 하여 plate shaker에 1시간 동안 방치하여 항원-항체반응을 유 도하였다. 1시간 후 상층액을 제거하고, wash buffer (350 l) 를 이용하여 비특이적으로 결합된 단백질이나 결합되지 않은 단백질을 세척하였다. 여기에 $200 \mu 1$ 의 substrate (TMB)을 첨 가하여 실온에서 15 분 동안 효소반응을 유도한 뒤 $50 \mu$ 의 stop solution을 첨가하여 반응을 종결하였다. 반응종결에 따라 나 타난 변화는 ELISA-reader (VERSA max, micro-reader, MDS. $\mathrm{Co}, \mathrm{USA}$ )를 이용하여 $450 \mathrm{~nm}$ 에서 측정하였다.

\section{면역염색}

랫드에서 적출한 췌장을 $10 \%$ formalin용액에 고정한 뒤, 조직처리기(Thermo Shandon Ltd./Thermo Fisher Scientific, England)와 Paraffin Embedding Station (LEICA 
MICROSYSTEMS NUSSLOCH GMBH, Germany)을 이용하 여 블록을 만들어 Rotary Microtome (LEICA MICROSYSTEMS NUSSLOCH GMBH, Germany)을 사용하여 박절하였다. 박절 된 조직의 면역염색을 실시하기 위하여 xylene과 ethanol에 담근 뒤, $3 \% \mathrm{H}_{2} \mathrm{O}_{2}$ 에 10 분간 배양한 후 $1 \mathrm{X}$ PBS로 세척하였다. $10 \% \mathrm{BSA}$ 에 담궈 10 분간 blocking 한 뒤에 인슐린항체 Antibody (\#4590, Cell Signaling Technology)와 1\% BSA를 1:100 농도로 희석한 뒤에 슬라이드에 100 씨씩 떨어뜨려 밤새 배양하였다. 1X PBS로 세척한 후에 Polink-2 Plus HRP Detection Kit for Rabbit Primary Antibody (with DAB chromogen) (Golden Bridge International, USA)를 이용하여 염색하고 permounting를 실시한 후 현미경을 이용하여 관찰 하였다.

\section{혈청 분석}

LP9M80-H이 OLETF 랫드의 혈청에 미치는 영향을 관찰하 기 위하여 혈청내 지질의 농도를 관찰하였다. 랫드를 약 8 시간 동안 절식하여 $\mathrm{CO}_{2}$ 가스를 이용하여 안락사한 후 혈액을 채취 하였다. 채취한 혈액은 상온에서 30 분 동안 방치한 후 원심 분리하여 혈청을 수확하였으며, 혈청 내 단백질의 변화는 혈 청분석기(HITACHI 7080 Automatic Analyzer, Japan)를 이용 하여 triglyceride, cholesterol, LDL의 3개 항목에 대하여 분석 하였다.

\section{Western Blot 분석}

인슐린 수용체 신호전달과정의 변화를 관찰하기 위하여, 실험동물로부터 간 조직을 추출하여 $100 \mathrm{mg}$ 에 PRO-PREP Protein Extraction Solution (iNtRON Biotechnology, 17081) 을 첨가하여 분쇄한 후 $13,000 \mathrm{rpm}$ 에서 5 분 동안 원심분리하 여 단백질을 분리하고, SMARTTM BCA Protein Assay Kit (iNtRON Biotechnology, 21071)을 이용하여 단백질을 정량하 여 western blot 분석에 사용하였다. 4-20\% SDS-PAGE gel에 $50 \mu \mathrm{g}$ 의 단백질을 전기영동한 후 $\mathrm{ECL}$ membrane (Amersham Life Science, RPN2020D)에 전이하고, 3\% skim milk에서 2시간 동안 블로킹하였다. 각 membrane은 Insulin Receptor $\beta$ (Cellsignaling, 3025s), IRS-1 (Cellsignaling, 3407s), Glut-2 (abcam, ab554460), Glut-3 (abcam, ab15311), Glut-4 (abcam, ab41529)로 $4^{\circ} \mathrm{C}$ 에서 밤새 배양한 후 HRP-conjugated secondary antibody를 첨가하여 ECL Kit (Amersham Life Science, RPN2108)를 이용하여 발광량을 측 정하였다.

\section{통계학적 분석}

대조군 LETO 랫드와 OLETF 랫드 사이에 통계적 유의성은 one-way ANOVA 분석(SPSS for windows, Release 10.01; SPSS, USA)을 이용하여 실시하였고, OLETF 랫드 내에서 vehicle 처리군과 LP9M80-H 처리군 간의 통계적 유의성은 $\mathrm{T}$-test를 이용하여 실시하였다. 모든 값은 평균 $\pm \mathrm{SD}$ 로 제시하 였고, 유의성 값은 $p<0.05$ 로 설정하였다.

\section{결 과}

LP9M80-H가 OLETF 랫드의 체중과 복부 지방량에 미치 는 영향

LP9M80-H가 비만과 당뇨가 유발된 실험동물인 OLETF 랫 드의 체중과 복부 지방량에 어떠한 영향을 미치는지 관찰하기 위하여 경구투여 전과 부검 전에 체중을 측정하였고, 부검시 복부지방을 적출하여 무게를 측정하였다. 그 결과, LETO 랫드 에 비해서 OLETF 랫드의 체중은 유의적으로 증가하였다. 그 러나 LP9M80-H를 투여한 OLETF 랫드는 vehicle군에 비하여 체중이 약간 감소하는 경향을 나타내었으나 두 집단 사이에서 유의적인 차이는 없었다(Fig. 2A). 또한, 복부지방의 무게도 OLETF 랫드가 LETO 랫드보다 유의적으로 증가하였다. 그러 나 LP9M80-H를 처리한 랫드는 vehicle군에 비하여 유의적으 로 복부지방이 약 $18 \%$ 정도 감소하였다(Fig. 2B). 이러한 결과 로부터 OLETF 랫드가 비만이 유발된 실험동물임을 확인 할 수 있었고, LP9M80-H 처리는 체중에 유의적인 영향을 미치지

$\mathbf{A}$

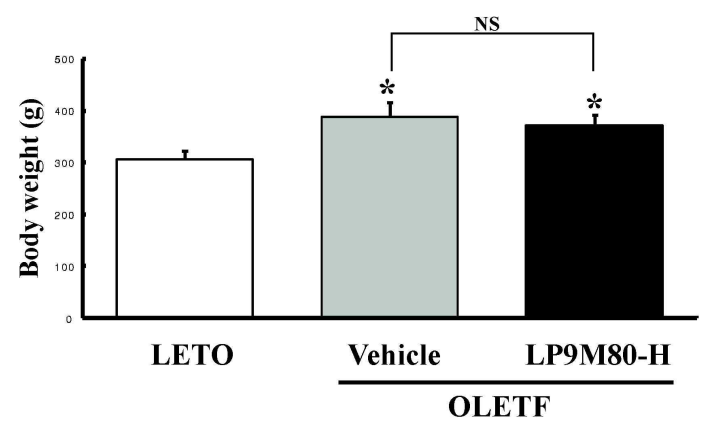

B

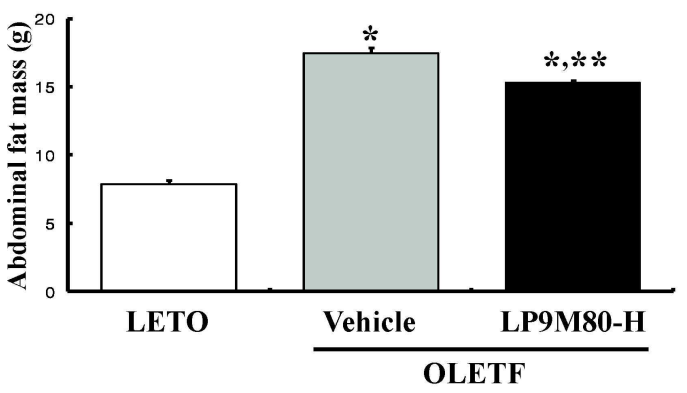

Fig. 2. Effects of LP9M80H on body weight and abdominal fat mass of OLETF rats. At $24 \mathrm{hr}$ after final LP9M80-H treatment, the body weight (A) and abdominal fat mass (B) of OLETF rats were measured with an electronic balance every day. The data represents the mean \pm SEM from three replicates. ${ }^{*} p<0.05$ is the significance level compared to LETO group. ${ }^{* *} p<0.05$ is the significance level compared to the vehicle-treated group. 
않지만 복부지방을 감소시키는 효과가 있음을 나타내고 있다.

\section{LP9M80-H가 OLETF 랫드의 혈당 조절에 미치는 영향}

LP9M80-H가 혈당량에 미치는 영향을 평가하기 위해 OLETF 랫드에 마지막으로 추출물을 투여하고 8시간 동안 절 식시킨 뒤, 랫드의 혈액을 채취하여 혈당량을 측정하였다. 그 결과, LETO 랫드는 약 $110 \mathrm{mg} / \mathrm{dl}$ 이고 OLETF 랫드가 약 100 $\mathrm{mg} / \mathrm{dl}$ 으로 약간은 감소하였으나 유의적인 차이는 없었다. 그 러나 LP9M80-H를 투여한 OLETF 랫드는 vehicle 처리한 랫드 에 비해 유의적으로 혈당이 감소하였다(Fig. 3A). 이러한 결과 는 LP9M80-H는 OLETF 랫드의 혈당을 감소시키는 효과를 나타낼 수 있음을 제시하고 있다.

\section{LP9M80-H가 인슐린의 분비에 미치는 영향}

인슐린은 체내의 혈당변화를 조절하는 중요한 역할을 하는 인자이다. 따라서, LP9M80-H 처리에 의한 혈당의 변화가 인 슐린에 의해 유도되는지 확인하기 위해 혈청내 인슐린의 변화 를 ELISA kit를 이용하여 분석하였다. 그 결과, OLETF 랫드는

A

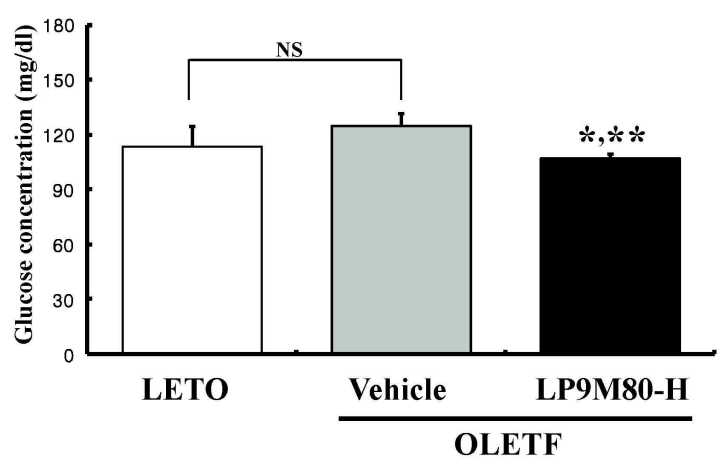

B

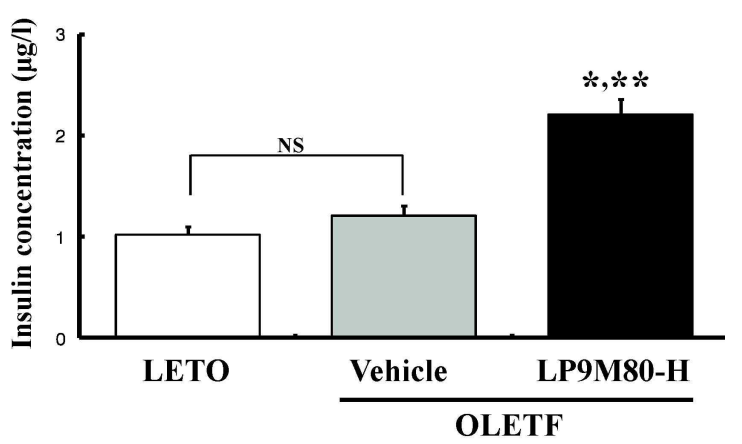

Fig. 3. Effects of LP9M80-H on blood glucose and insulin concentration. Blood was collected from the abdominal veins of the vehicle-treated rats and LP9M80H-treated rats. Glucose level was measured by a CareSence Kit (A) and the insulin level was determined using an insulin ELISA kit (B). The data represents the mean \pm SEM from three replicates. ${ }^{*} p<0.05$ is the significance level compared to LETO group. ${ }^{* *} p<0.05$ is the significance level compared to the vehicle-treated group.
LETO 랫드와 혈청내 인슐린의 농도에 유의적인 차이가 없었 으나, LP9M80-H를 처리한 랫드는 인슐린의 분비량이 급속히 증가하였다(Fig. 3 B). 또한, 이러한 혈청내 인슐린 농도의 변화 가 인슐린 분비기관인 췌장조직의 베타-세포에서도 변화를 나 타내는지 확인하기 위해 면역염색을 실시하였다. 그 결과, 혈 청 내 인슐린 농도의 변화와 유사한 양상이 인슐린 면역염색 에서도 관찰되었다. 췌장세포에서 확인된 인슐린 농도는 OLETF 랫드가 LETO 랫드보다 약간 증가하였으며, LP9M80-H를 처리한 OLETF 랫드에서는 급격히 증가하였다 (Fig. 4). 따라서 이러한 결과는 LP9M80-H는 OLETF 랫드에서 인슐린분비를 촉진시키는 역할을 함을 제시하고 있다.

\section{LP9M80-H가 지방대사에 미치는 영향}

Adiponectin은 Adipo 유전자에 의해 발현되는 지방세포에 서 분비되는 단백질 호르몬으로 식욕조절 및 체내 지방축적을 조절하고, 인슐린 민감도와 세포생존을 촉진시키며, 염증을 감소시킨다[5]. LP9M80-H가 혈청 내 adiponectin의 농도에 미 치는 영향을 관찰하기 위하여 ELISA kit를 이용하여 LETO 랫드와 OLETF 랫드에서 분리된 혈청에서 adiponectin 농도를 측정하였다. 그 결과, adiponectin의 농도는 OLETF 랫드가 LETO 랫드보다 유의적으로 약 $45 \%$ 정도 증가하였으며, LP9M80-H를 처리한 랫드에서는 LETO 랫드의 수준으로 감소 하였다(Fig. 5A). 이러한 결과는 LP9M80-H는 OLETF 랫드의 지방세포에서 adiponectin의 분비를 정상수준으로 회복시켜 주는 기능을 나타냄을 제시하고 있다.

또한, LP9M80-H가 혈청 내 지방의 농도에 미치는 영향을 관찰하기 위하여 실험군의 랫드에서 분리된 혈청을 이용하 여 Triglyceride (TG), Cholesterol (Chol), Low Density Lipoprotein $(\mathrm{LDL})$ 의 농도변화를 관찰하였다. 그 결과, $\mathrm{TG}$ 의 농도는 OLETF 랫드가 LETO 랫드보다 급격히 증가하였으 며, LP9M80-H을 처리한 랫드에서는 유의적으로 약간 감소 하였다(Fig. $5 \mathrm{~B}$ ). 그러나 Chol과 LDL의 농도는 vehicle을 처 리한 OLETF 랫드에서 증가하였으나, LP9M80-H을 처리한 OLETF 랫드에서는 LETO 랫드의 수준으로 감소하였다(Fig. 5C, Fig. 5D). 이러한 결과는 LP9M80-H는 OLETF 랫드에서 혈청 내 지방을 효과적으로 감소시키는 효과를 나타냄을 제 시하고 있다.

LP9M80-H가 인슐린 수용체 신호전달과정과 Gluts의 발 현에 미치는 영향

체내에 분비된 인슐린은 표적장기의 세포표면에 발현되는 인슐린 수용체와 결합하여 IRS-1을 통한 신호를 전달하며, 이 러한 신호는 Gluts의 발현을 비롯한 다양한 세포내 신호전달 과정을 조절한다[4]. 따라서 LP9M80-H에 의해서 혈청 내 증가 된 인슐린이 표적세포의 인슐린 수용체 신호전달과정과 Gluts 에 미치는 영향을 관찰하기 위하여 간세포를 이용하여 단백질 

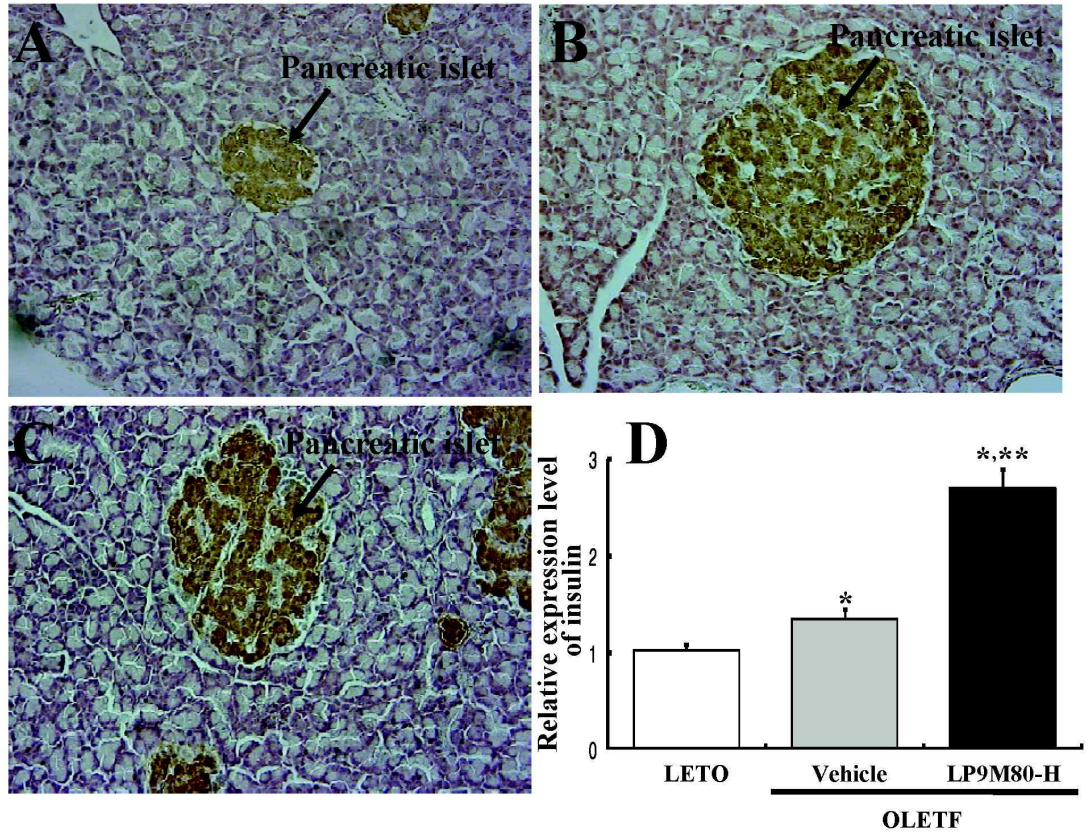

Fig. 4. Immunostaining analysis for insulin expression. The expression level of insulin was detected in the pancreatic islets of vehicle-treated and LP9M80-H-treated rat by immunostaining analysis. A high intensity was observed in the pancreatic islets of the LP9M80-H-treated rat as compared with the vehicle-treated rats at 200x magnification. The data represents the mean \pm SEM from three replicates. ${ }^{*} p<0.05$ is the significance level compared to LETO group. ${ }^{* *} p<0.05$ is the significance level compared to the vehicle-treated group.

A

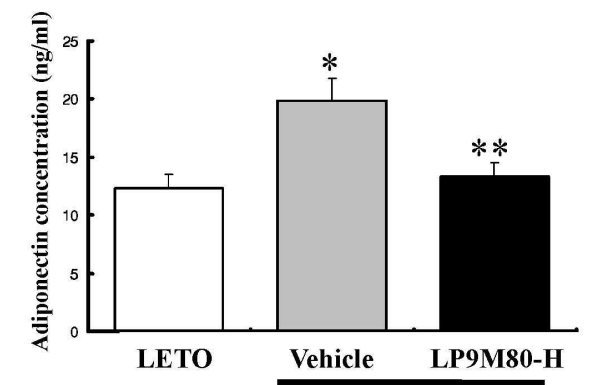

C

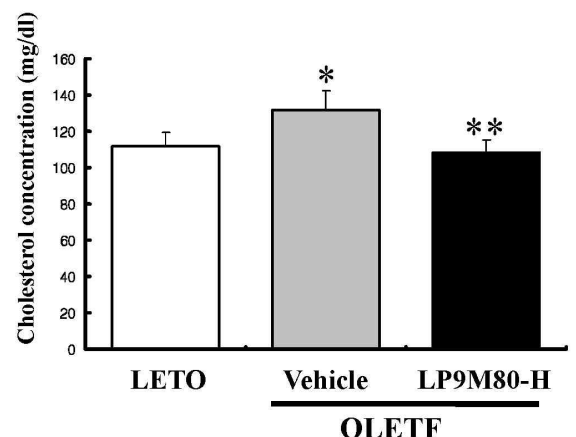

B

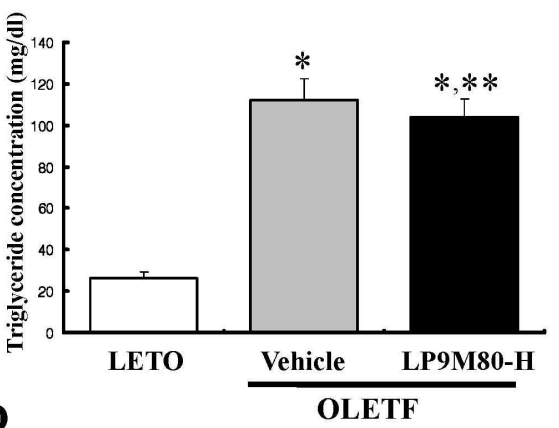

D

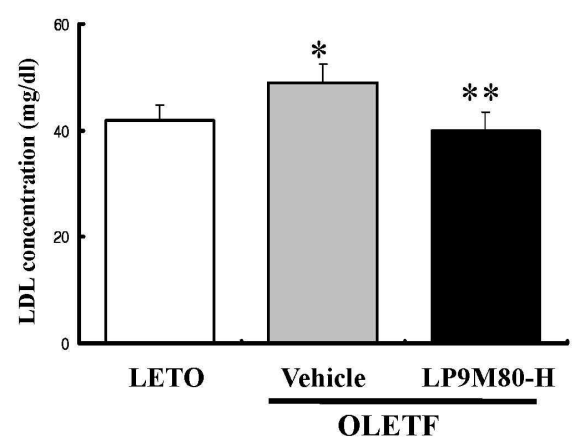

Fig. 5. Concentration of adiponectin and lipid concentration in serum. Blood was collected from abdominal vein of the rats, and (A) adiponectin level in serum was analyzed using ELISA kit. This kit has $0.1 \mathrm{ng} / \mathrm{ml}$ of sensitivity and interassay coefficient of variation was $2.86-5.17 \mathrm{ng} / \mathrm{ml}$ range. (B) The level of triglyceride, cholesterol and LDL were analyzed in triplicate using serum biochemical analyzer. The values are the mean \pm SD. ${ }^{*} p<0.05$ is the significance level compare to the LETO rats. ${ }^{* *} p<0.05$ is the significance level compare to the vehicle-treated OLETF rats. 
발현의 변화를 관찰하였다. 그 결과, OLETF 랫드의 간세포에 서 인슐린 수용체 $\beta$ 의 발현은 LETO 랫드보다 감소하였으며, LP9M80-H를 처리한 랫드의 간세포에서는 유의적으로 증가 하였다. 또한, 인슐린 수용체의 downstream에서 신호를 전달 하는 IRS-1의 발현은 인슐린 수용체와 비슷한 발현양상을 나 타내었다. Vehicle처리한 OLETF 랫드에서 IRS-1의 발현은 LETO 랫드보다 감소하였으며, LP9M80-H를 처리한 OLETF 랫드에서는 증가되어 LETO 랫드 수준으로 회복되었다(Fig. 6A). 이러한 결과는 LP9M80-H는 OLETF 랫드에서 발현이 감 소된 인슐린 수용체 $\beta$ 와 IRS- 1 의 발현의 증가를 유도하는 효 과가 있음을 제시하고 있다.

또한, 간 조직에서 3 종류의 Gluts 발현을 분석한 결과, OLETF 랫드에서 Glut-2와 Glut-4의 발현은 LETO 랫드보다 유의적으로 증가하였고, LP9M80-H를 처리한 OLETF 랫드에 서는 발현량이 더욱 증가하였다. 그러나 Glut-3발현은 OLETF 랫드와 LETO 랫드에서 유의적인 차이가 없었으나 LP9M80-H 를 처리한 랫드에서는 발현이 감소하였다(Fig. 6B). 이러한 결 과는 LP9M80-H는 Gluts발현을 조절할 수 있음을 제시하고 있다.

\section{고 찰}

비정상적인 인슐린 조절, 지질 및 탄수화물 대사 장애가 특징인 당뇨병은 전세계의 주요 건강 문제 중 하나이다[1]. 일반적으로 당뇨병은 고혈당증과 심혈관증과 신장병, 망막 병증 및 신경 장애와 관련된 심각한 합병증을 초래한다[20]. 당뇨병의 발병기전으로는 크게 두 가지가 알려져 있으며, 제 1 형 당뇨병은 췌장베타세포가 기능을 상실하여 인슐린을 제대로 분비하지 못하게 되는 것이다. 제 2 형 당뇨병은 췌장 베타세포에서 인슐린이 정상적으로 생산되지만 이들이 분 비되지 못하거나 혹은 표적조직 내에 수용체의 이상으로 정 상적인 신호전달과정이 발생하지 못하여 발생하며, 인슐린 비의존성당뇨(Non-insulin dependent diabetes)라고 한다 $[10,20]$. 전체 당뇨환자의 $90 \%$ 가 제 2 형 당뇨증상을 나타내기 때문에 많은 연구가 활발히 진행되고 있으나 아직 효과적인 치료제가 개발되지 못하고 있다. 따라서 본 연구에서도 제2 형 당뇨질환에 대한 효과를 평가하기 위해 OLETF 랫드 모 델을 이용한 실험을 수행하였다. 현재까지 많은 설치류 당 뇨병 모델이 개발되어 있으며, 그 중에서 OLETF 랫드는 인 슐린 저항성을 가진 제2형 당뇨병 연구에 널리 사용되는 모 델이다. 또한 OLETF 랫드는 과식증, 비만, 고인슐린증에도 널리 사용되고 있다[13,17].

새로운 당뇨병 치료제를 개발하기 위한 연구 중에서 인슐린 조절에 효과적인 천연식물을 찾는 연구가 활발히 진행되고 있다. 제 2 형 당뇨병의 치료에 사용되고 있는 약물인 Troglitazone은 일본에 서식하는 식물에서 추출하여 만든 인
A

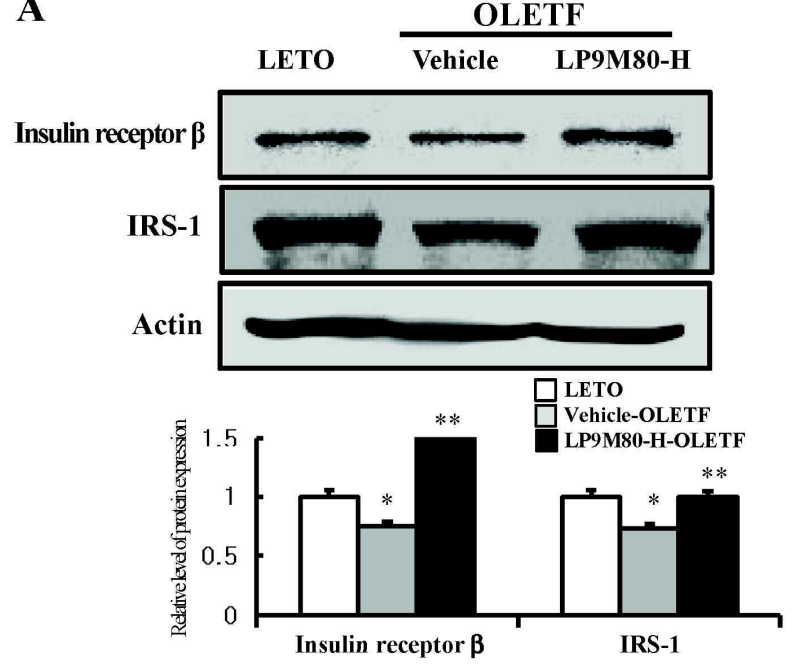

B

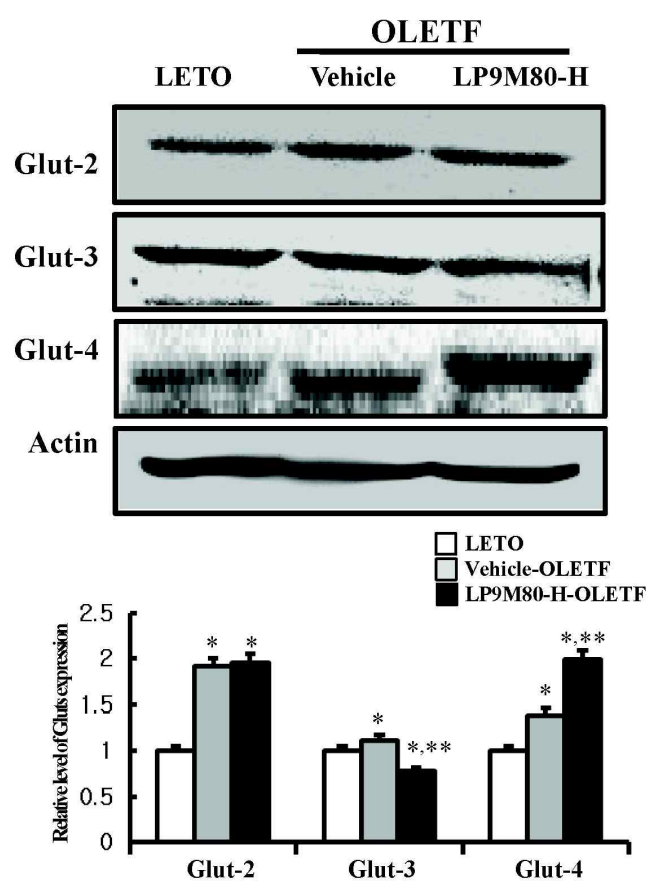

Fig. 6. Insulin receptor-related factors and Gluts expression in liver. Tissue lysates were prepared from liver tissue of vehicle-treated and LP9M80-H-treated rats. Fifty micrograms of protein per sample were immunoblotted with antibody for each protein. Insulin receptor, IRS-1 and Gluts protein expression was detected with each primary antibody and horseradise peroxidase-conjugated goat anti-rabbit IgG. The intensity of each protein was calculated using an imaging densitometer. The data represents the mean \pm SEM from three replicates. ${ }^{*} p<0.05$ is the significance level compare to the LETO rats. ${ }^{* *} p<0.05$ is the significance level compare to the vehicle-treated OLETF rats.

슐린 저항성을 감소시키는 것으로 최초로 개발된 약물이다. 하지만 Troglitazone을 투여한 동물실험에서 간 독성이 나타 
났다[7,12]. 또한, 둥글레 추출물도 인슐린 민감성을 촉진하여 항고혈 당증을 완화시켜 주었고[2], 옻나무의 주요 플라보노이 드인 Sulfuretin은 streptozotocin에 의해 유발된 고혈당증 및 저인슐린혈증을 억제하였다[16]. 본 연구에서 사용된 맥문동 은 이전부터 당뇨 및 비만에 대한 치료효능이 있는 것으로 알려지면서 개발 가능성이 매우 높은 후보물질이다[3,13]. 따 라서 본 연구에서는 맥문동의 새로운 치료제로서의 발전 가능 성을 기반으로 당뇨 및 비만에서 효능과 기전에 대한 메커니 즘을 증명하고자 후보물질로 선정하여 연구를 수행하였다.

맥문동의 당뇨 및 비만질환연구를 위해 다양한 형태의 추출 물들이 사용되었다. 단순히 물을 이용하여 추출한 유수추출물 [4], $70 \% \mathrm{MeOH}$ 을 이용하여 추출한 추출물[3], $80 \% \mathrm{MeOH}$ 과 hexane을 이용하여 추출한 추출물[13] 그리고 맥문동의 일부 를 첨가하여 다른 추출물과 혼합한 물질[8]을 이용한 연구 등 이 수행되었다. 본 연구에서는 이전에 본 연구실에서 ICR마우 스를 이용하여 맥문동의 당뇨 치료효능을 연구하는데 사용한 $80 \% \mathrm{MeOH}$ 과 hexane 추출물인 LP9M80-H를 사용하여 분석 하였다(Fig. 1).

실험동물의 체중은 질병의 변화를 일차적으로 확인할 수 있는 좋은 지표이다. 맥문동이 포함된 경신강제환을 투여한 OLETF 랫드의 체중은 유의적으로 감소하였지만[8], 본 실험 에서는 체중의 변화가 유의적으로 관찰되지 않았다. 이것은 투여물질의 종류, 혹은 투여기간에 기인한 것으로 사료된다.

혈당을 조절하는 인슐린은 LP9M80-H를 처리한 ICR마우스 [13] 그리고 증숙 된 맥문동의 유수추출물을 처리한 streptozotocin (STZ) 유발 당뇨 ICR 마우스에서[4] 모두 증가하였다. 비록 증가량은 각 실험에서 조금씩 차이가 있지만 OLETF 랫 드를 이용한 본 실험에서도 인슐린의 분비는 유의적으로 크게 증가하였다. 이러한 결과로부터 맥문동은 추출물의 형태에 상 관없이 인슐린 분비를 촉진하는 기능이 있음을 제시할 수 있 다. 또한, 표적세포 중에서 3T3-L1 adipocytes는 70\% $\mathrm{MeOH}$ 추출물을 처리하여 인슐린 up-take의 증가를 유도하였으나 [3], 본 실험에서는 확인되지 않아 향후 실험에서 확인이 필요 할 것으로 사료된다.

한편, 인슐린 수용체의 발현변화는 오직 하나의 논문에서만 관찰되었다. 맥문동의 $70 \% \mathrm{MeOH}$ 추출물은 3T3-L1 adipocytes에서 인슐린 수용체와 IRS-1의 발현을 촉진시켰으며[3], 이러한 결과는 OLETF 모델 동물의 간을 이용한 본 실험에서 도 동일하게 관찰되었다. 비록 OLETF 랫드의 간에서 이들 단 백질의 발현은 LETO 랫드의 간에서보다 낮지만 LP9M80-H를 처리하면 유의적으로 증가되었다. 이러한 결과로부터 인슐린 수용체의 작용이 지방세포와 간세포에서 효과적으로 발생할 수 있음을 확인하였다.

Gluts는 인슐린수용체의 신호전달과정을 통해 표적세포에 서 발생하는 glucose대사를 조절하는 단백질이며, 인슐린에 의해 발현양의 변화가 관찰된다[13]. 다양한 Gluts 중에서 본
연구에서는 Glut-2, 3 그리고 4를 관찰하였다. 맥문동의 $70 \%$ $\mathrm{MeOH}$ 추출물을 투여한 실험에서 adipocyte는 Glut-4발현 증 가를 유도하였으며[3], 이러한 결과는 간세포를 이용한 본 실 험결과와 매우 유사하였다. 또한, 본 실험과 동일한 물질을 ICR 마우스에 처리한 실험에서는 Glut-3가 유의적으로 증가 하였지만 OLETF 랫드 모델 동물을 이용한 본 연구에서는 Glut-3가 감소하는 결과를 관찰하였다. 이러한 차이는 OLETF 랫드가 표적세포의 이상으로 발생하는 제 2 형 당뇨이기 때문 에 간세포에서 정상적인 신호전달과정이 이루어지지 않고 있 기 때문인 것으로 사료된다. 증숙 가공된 맥문동을 STZ 유발 당뇨 ICR 마우스에 처리한 경우, Glut-2와 Glut-3가 모두 증가 하였다[4]. 그러나 본 연구에서는 Glut-2는 발현량에 변화가 없었으며, Glut-3는 오히려 감소하였다. 이러한 차이도 제1형 당뇨와 제 2 형당뇨 모델동물의 차이로 해석할 수 있다.

이상의 결과를 종합해보면, 맥문동의 $\mathrm{MeOH}$ 과 hexane 추 출물인 LP9M80-H는 지방의 무게를 줄여주는 효과가 우수하 며, 인슐린 분비를 촉진시켜 당뇨를 개선하는 기능을 갖고 있다. 이러한 결과를 토대로, 맥문동 추출물의 순수성분을 찾 아내고 기능과 메카니즘 연구를 병행한다면 항당뇨와 항비 만 효능을 갖는 우수한 치료제를 개발 할 수 있을 것으로 사 료된다.

\section{감사의 글}

본 연구는 농림수산식품기술기획평가원의 지원을 받아 수 행하였으며, 질환모델동물의 제공에 협조하여 준 일본 오츠카 제약(주)와 한국 중앙실험동물(주)에 감사의 마음을 전합니다.

\section{References}

1. Atalay, M. and Laaksonen, D. E. 2002. Diabetes, oxidative stress and physical exercise. J. Sports Sci. Med 1, 1-14.

2. Choi, S. B. and Park, S. 2002. A steroidal glycoside from Polygonatum (Mill.) odoratum Druce improves insulin resistance but does not alter insulin secretion in $90 \%$ pancreatectomized rats. Biosci. Biotech Biochem 66, 2036-2043.

3. Choi, S. B., Wha, J. D. and Park, S. 2004. The insulin sensitizing effect of homoisoflavone-enriched fraction in Liriope platyphylla Wang et Tang via PI3-kinase pathway. Life Sci. 75, 2653-2664.

4. Choi, S. I., Lee, H. R., Goo, J. S., Kim, J. E., Nam, S. H., Hwang, I. S., Lee, Y. J., Park, S. H., Lee, H. S., Lee, J. S., Jang, I. S., Son, H. J. and Hwang, D. Y. 2011. Effects of Steaming Time and Frequency for Manufactured Red Liriope platyphylla on the Insulin Secretion Ability and Insulin Receptor Signaling Pathway. Lab. Anim Res. 27, 117-126.

5. Gil, J. H., Lee, J. A., Kim, J. Y. and Hong, Y. M. 2008. Leptin, adiponectin, interleukin- 6 and tumor necrosis factor-a in obese adolescents. Korea J. Pediatrics 51, 597-603. 
6. Idris, I. and Donnelly, R. 2009. Sodium-glucose co-transporter-2 inhibitors: an emerging new class of oral antidiabetic drug. Diabetes Obes. Metab. 11, 79-88.

7. Iwanishi, M. and Kobayash, M. 1993. Effects of pioglitazone on insulin receptors skeletal muscle from high-fat-fed rats. Metabolism 42, 1017-1021.

8. Jeong, S. H., Chae, K. S., Jung, Y. S., Rho, Y. H., Lee, J. M., Ha, J. R., Yoon, K. H., Kim, G. C., Oh, K. S., Shin, S. S. and Yoon, M. C. 2008. The Korean traditional medicine Gyeongshingangjeehwan inhibits obesity through the regulation of leptin and PPARalpha action in OLETF rats. J. Ethnopharmacology 119, 245-251.

9. Jung, M., Park, M., Lee, H. C., Kang, Y. H., Kang, E. S. and Kim, S. K. 2006. Antidiabetic agents from medicinal plants. Curr. Med Chem 13, 1203-12018.

10. Kim, J. H., Kim, J. E., Lee, Y. K., Nam, S. H., Her, Y. K., Jee, S. W., Kim, S. G., Park, D. J., Choi, Y. W. and Hwang, D. Y. 2010. The extracts from Liriope platyphylla significantly stimulated insulin secretion in the HIT-T15 pancreatic $\beta$-cell line. J. Life Sci. 7, 1027-1033.

11. Kokil, G. R., Rewatkar, P. V., Verma, A., Thareja, S. and Naik, S. R. 2010. Pharmacology and chemistry of diabetes mellitus and antidiabetic drugs: a critical review. Curr. Med Chem 17, 4405-4423.

12. Kreagen, E. W., James, D. E. and Jenkins, A. B. 1989. A potent in vivo effect of ciglitazone on muscle insulin resistance induced by high fact feeding of rats. Metabolism 38, 1089-1093.

13. Lee, Y. K., Kim, J. E., Nam, S. H., Goo, J. S., Choi, S. I., Choi, Y. H., Bae, C. J., Woo, J. M., Cho, J. S. and Hwang, D. Y. 2011. Differential regulation of the biosynthesis of glucose transporters by the PI3-K and MAPK pathways of insulin signaling by treatment with novel compounds from Liriope platyphylla. Int. J. Mol. Med 27, 319-327.

14. Prabhakar, P. K. and Doble, M. 2008. A target based therapeutic approach towards diabetes mellitus using medicinal plants. Curr. Diabetes Rev. 4, 291-308.

15. Seong, J. D., Park, K. D., Kwack, Y. H., Kim, S. M. and Kang, J. H. 2000. Effects of nitrogen levels and split application ratio on growth and yield in Liriope platyphylla WANG et TANG. Korean J. Medicinal Crop Sci. 8, 69-73.

16. Song, M. Y., Jeong, G. S., Kwon, K. B., Ka, S. O., Jang, H. Y., Park, J. W., Kim, Y. C. and Park, B. H. 2010. Sulfuretin protects against cytokine-induced beta-cell damage and preventss treptozotocin-induced diabetes. Exp. Mol. Med 42, 628-638.

17. Tomoe, F., Hiroyuki, K., Chiyo, T., Yuko, K., Kazuhiko, O., Takahisa, Y. and Kozo, M. 2011. Genetic interaction between hyperglycemic QLTs is manifested under a high calorie diet in OLETF-derived congenic rats. Exp. Anim 60, 125-132.

18. Wild, S., Roglic, G., Green, A., Sicree, R. and King, H. 2004. Global prevalence of diabetes: estimates for 2000 and projections for 2030. Diabetes Care 27, 1047-1053.

19. Won, J. Y. and Lee, C. Y. 2002. Characteristics of photosynthesis and dry matter production of Liriope platyphylla WANG et TANG. Korea J. Medicinal Crop Sci. 10, 82-87.

20. Zimmet, P. Z., McCarty, D. J. and Courten, M. P. 1997. The blobal epidemiology of non-insulin-dependent diabetes mellitus and the metabolic syndrome. J. Diabetes Complicat. 11, 60-68.

\section{초록 : OLETF 당뇨모델동물을 이용한 맥문동 추출물(LP9M80-H)의 당뇨질환에 대한 효능}

김지은 ${ }^{1}$ 황인식 ${ }^{1} \cdot$ 구준서 $^{1} \cdot$ 남소희 $^{1} \cdot$ 최선일 ${ }^{1} \cdot$ 이혜련 ${ }^{1} \cdot$ 이영주 $^{1} \cdot$ 김윤한 $^{2} \cdot$ 박세진 $^{2} \cdot$ 김남수 $^{3} \cdot$ 최영환 ${ }^{2} \cdot$

황대연 ${ }^{1} \star$

(부산대학교 생명자원과학대학 ${ }^{1}$ 바이오소재과학과, ${ }^{2}$ 원예생명과학과, ${ }^{3}$ 농촌진흥청)

LP9M80-H는 맥문동(Liriope platyphylla)으로부터 메탄올과 헥산을 이용하여 추출한 새로운 추출물로서 ICR 마우 스에서 인슐린분비를 촉진하며, 간과 뇌 조직에서 인슐린 신호경로를 활성화시키는 것으로 알려져 있다. 본 연구에 서는 LP9M80-H가 당뇨와 비만의 치료에 미치는 효과를 조사하기 위하여, OLETF 모델동물에 LP9M80-H를 2주간 투여한 후 당뇨와 비만과 관련된 주요인자의 변화를 관찰하였다. 비록 체중은 두 집단간에 차이가 없었으나 복부 지방량은 vehicle 투여군보다 LP9M80-H 투여군에서 적었다. 또한, 혈중 포도당농도는 LP9M80-H를 투여한 OLETF 랫드가 대조군에 비하여 약간 낮았으나 인슐린의 농도는 유의적으로 크게 증가하였다. 혈청 내 3가지 주요 지질의 농도는 LP9M80-H를 투여한 OLETF 랫드에서 유의적으로 감소하였고, 지방의 산화를 촉진하는 아디포넥틴의 농도 도 LP9M80-H를 투여한 OLETF 랫드에서 감소하였다. 더불어, 체내에 분비된 인슐린이 표적장기에 미치는 영향을 관찰하기 위하여 간조직에서 인슐린 수용체와 인슐린 수용체기질(IRS)의 발현을 관찰하였으며, 이러한 2가지 단백 질은 LP9M80-H를 투여한 OLETF 랫드에서 vehicle 투여군에 비해 유의미하게 감소하였다. 또한, 인슐린 신호 경로의 다운스트림에 위치하는 포도당 수송체 중에서 Glut-2와 Glut-3 발현은 LP9M80-H를 투여한 OLETF 랫드에 서 유의미하게 감소하는 반면에, Glut-4 발현은 일정하게 유지되었다. 따라서 이러한 결과는 LP9M80-H는 포도당 항상성과 지질농도의 조절을 통하여 당뇨와 비만의 증상을 완화시키는데 기여할 것으로 사료된다. 